\title{
Long-Term Impacts of Cultivation and Residue Burning Practices on Soil Carbon and Nitrogen Contents in Cambisols of Southwestern Ethiopia
}

\author{
Yacob Alemayehu Ademe* \\ Department of Plant Science, College Agriculture and Natural Resource, Dilla University, Dilla, Ethiopia
}

Email address:

jaxx602@yahoo.com, yacobalem@gmail.com

To cite this article:

Yacob Alemayehu Ademe. Long-Term Impacts of Cultivation and Residue Burning Practices on Soil Carbon and Nitrogen Contents in Cambisols of Southwestern Ethiopia. American Journal of Agriculture and Forestry. Vol. 3, No. 3, 2015, pp. 65-72.

doi: 10.11648/j.ajaf.20150303.11

\begin{abstract}
Soil organic carbon (OC) and total nitrogen $(\mathrm{N})$ are important indices for evaluating land management system, so that assessing the management effects on soil $\mathrm{OC}$ and total $\mathrm{N}$ dynamics is essential for addressing sustainable land productivity and environmental quality issues. This study was carried out to determine the impact of long-term agricultural practices on the distribution and contents of $\mathrm{OC}$ and total $\mathrm{N}$ in Cambisols of Abobo, southwestern Ethiopia. Three adjacent fields: Cultivated field with continuous residue burning (CB), Grassland with annual burning (GB) and the Virgin land with native vegetation (VL) were used in this study. The soil in VL was used as a reference to assess extent of changes in soil OC and total $\mathrm{N}$ contents. Composite soil samples were collected from four soil depths $(0-15,15-30,30-45$ and $45-60 \mathrm{~cm})$ of each land units, in the triplicate sites. A one-way ANOVA and correlation coefficient analysis were used to test the mean differences of the soil OC and total $\mathrm{N}$ contents in each soil depth, and to determine their degree of association with other soil variables. The result revealed that the existing management practices significantly affected soil OC and total $\mathrm{N}$ contents in all the studied soil depths. The depletion of soil OC and total N from CB and GB fields were up to 83 and $66 \%$, respectively, as compared to those in the VL. Changes in soil OC and total $\mathrm{N}$ were more pronounced in the top $30 \mathrm{~cm}$ depth of soil, although significant reduction observed in the 30 - to $60 \mathrm{~cm}$ depth. The contents of deeper soil layers $(45-60 \mathrm{~cm})$ in burned and burned/cultivated sites were comparable, implying that immediate fire/tillage impacts were restricted to the near surface soil depth. The overall results suggest that the existing land management is not sustainable; hence, proper residue management is imperative in order to sustain the soil quality and maintain long-term productivity of the farmland.
\end{abstract}

Keywords: Prolonged Cultivation, Residue Burning, Organic Carbon, Total Nitrogen, Soil Depth

\section{Introduction}

Soil organic carbon (OC) is one of the largest carbon pools on the earth's surface, accounting for $2344 \mathrm{Pg}(56 \%)$ of overall global carbon [1]. Soil OC contents play a vital role in sustaining soil fertility for crop production and environmental quality due to its effects on soil physical and chemical properties, as well as biological activities [2]. This implies that soil quality is highly linked with soil OC content, whose status depends on biomass input and management, mineralization, leaching and erosion of soil organic matter. A type of agricultural landuse and/or management practices has a significant factor that controls soil OC levels, since it affects the amount and quality of litter input, decomposition rates and the processes of OM $(\sim 58 \% \mathrm{C})$ balance in soils [3,
29]. For instance, removal or burning residues in the field causes considerable loss of organic $\mathrm{C}$ and $\mathrm{N}[8,9]$ and other nutrients by volatilization $[10,11]$, which might adversely affect soil microorganisms [12].

Ethiopia has one of the oldest agrarian cultures in the subSaharan Africa with a large agriculture potential. Today, agriculture is not only the backbone of the economy, but also a major occupation for nearly $83 \%$ of Ethiopia's inhabitants [9]. This sector is, however, beset by anthropogenic factors (land use/management systems) that adversely affect its productivity $[4,5]$. Improper land use and/or management practices mainly: continuous cultivation with low input, removal of crop residues (as animal feed or fuel wood) or burning plant residues as practiced under the traditional system of crop production are major contributors to the loss 
of soil OC and nutrients $[6,27]$ that aggravates the decline of quality and productive capacity of soils in various parts of the country $[5,6,7,13,33]$. Different rates of decline in OC and total $\mathrm{N}$ after cultivation of forest soils have been reported, but most contain a great reduction. In the western Alfisols of Ethiopia, Wakene and Heluf [13] reported losses in OC and total $\mathrm{N}$ of 79 and $76 \%$, respectively, from virgin soils after 40 year of cultivation. Tsehaye and Mohammed [14] found that surface $\mathrm{OC}$ and total $\mathrm{N}$ concentrations in Mollisols declined by $68 \%$ and $56 \%$, respectively, after cultivation as compared to that of natural forest counterpart. Also reported by Nega and Heluf [15], significant decreases in OC and total $\mathrm{N}$ up to a depth of $50 \mathrm{~cm}$, in fifty year continuously cropped field when compared with forestland. Elsewhere, Reeder et al. [16] reported a decline of 18 and $26 \%$ in surface soil OC and total $\mathrm{N}$, respectively, after sixty year of intensive cropping in the Great Plains.

The present study targets Abobo area, southwestern Ethiopia, where agricultural pressure became higher over the past three decades, and recurrent residue burning (both cultivated and open field) practice is common traditional agriculture. In this area, fire is widely used by farmers to clear vegetation and crop residues (in every dry season), because it provides an easy and economical means of access to fields. In this regard, very little is known about the soil variables with long-term different management practices. Previous studies [17, 18] observed variations in soil properties (viz. OM content, soil depth) along landscapes of the area. However, the aforementioned researches merely compare variation soil properties as a function of landscape, and have tended to ignore the variation found due to differences in the existing land use and/or management practices. As land management effect varies depending on land use scenario (duration of land use, cropping systems, residue management) and climate of the area, it is impractical to take reported data from other areas to assess the situation in Abobo area. Hence, knowledge about the condition of soil quality indicators is vital for replenishing and maintaining soil fertility of the area.

In this work, it was hypothesized that soil OC and total $\mathrm{N}$ contents would vary due to the extended variation in land management practices in the site. Therefore, the objectives of this study were (i) to determine the quantity and the distribution of soil OC and total $\mathrm{N}$ at depths of fields affected by different land management practices (ii) to estimate the changes in $\mathrm{OC}$ and total $\mathrm{N}$ of soils under prolonged period of cultivation and burning practices that could contribute toward improved management of the agricultural land in the area.

\section{Materials and Methods}

\subsection{Location and Site Characteristics}

The study site is located in Gambella region, at the village of Abobo, southwest Ethiopia (Fig. 1). The agro-ecology of the area is typically hot to warm sub-humid lowlands [30] with mean annual rainfall of $1039.4 \mathrm{~mm}$ (uni-modal type), and mean annual temperature $26.4{ }^{\circ} \mathrm{C}$ [31]. Subsistent and mixed crop-livestock agriculture characterizes the farming system. The study site is flat terrain with elevation about 550 $\mathrm{m}$ a.s.l, and covering about 210 ha. The soils at the site were classified as Haplic Cambisols and Fluvi-Mollic Cambisols, according to WRB soil classification system [19], with moderately deep to deep soil profile and dark reddish brown color [18], and slightly acidic pH. For more understanding of the soil condition, selected physicochemical properties of soils of the site are presented in Table 1. The area is nearly level to gently sloping, and no salinity and drainage problems existed.

\subsection{Land Use/Management}

The study area is known to have a three distinguishable land use and/or management practices: namely long-term cultivated field, grassland and forest/shrub land. Based on the land use and/or management history, all the sites were similar before, and changes in land use have been introduced since the last three decades. Information on the land use and/or management history and characteristics of the site is briefly presented as follows:

Long-term cultivated field with annual residue burning $(C B)$ : The field has been cultivated continuously for about 30 years with annual mechanized plow, and cropped predominantly to maize (Zea mays L.), cotton (Gossypium hirsutum L.) and haricot bean (Phaseolus vulgaris L.). Small vegetation and crop residues burning in the dry season (January-March) of every year, has been common practice of land preparation for cultivation. It covers about 154 ha of land.

Grassland with annual burning practice $(G B)$ : the site occupied by annual grasses, mainly Sudan grass (Sorghum bicolor subsp. drummondii), which is used as forage for livestock. Similar to cultivated land, this field has been undergoing annual burning practice, for rejuvenation and establishment of the grass for better forage. This site has never been cultivated for several years, and covering nearly 36 ha.

Virgin forestland (VL): located adjacent to the Grassland field, which is occupied by various shrubs and tree species such as: Azadirachta indica, Acacia sp. and other local tree species. In addition, plantations have been established in early 1980 s.

\subsection{The Research Approach and Soil Sampling}

A necessary assumption made in this research approach was that soil conditions or parameters for all the sites should be similar before changes in the land use/management have been introduced. Accordingly, three treatments based on agricultural management practices: long-term cultivated field with annual residue burning (CB), grassland which had been received annual burning (GB), and virgin forestland (VL) were set up; with four sampling depths (0-15, 15-30, 30-45 and $45-60 \mathrm{~cm}$ ) for each. Three replicate sampling locations approximately $200 \mathrm{~m}$ apart were bordered within the specific 
land unit.

The replicate fields were sampled randomly over the whole area. At the time of soil sampling (in March, 2012), both under cultivation and grassland had been received residue burning, as usual as it was done before. A total of 36 composite soil samples (each composite sample made from a pool of 9 subsamples) were collected from each sampling depth of soils of the three land management classes. The sites had comparable slope (gradient and aspect) and parent materials they developed [18], hence, similarity in slope and topographical conditions among sampling plots were maintained as much as possible in order to minimize extraneous errors.

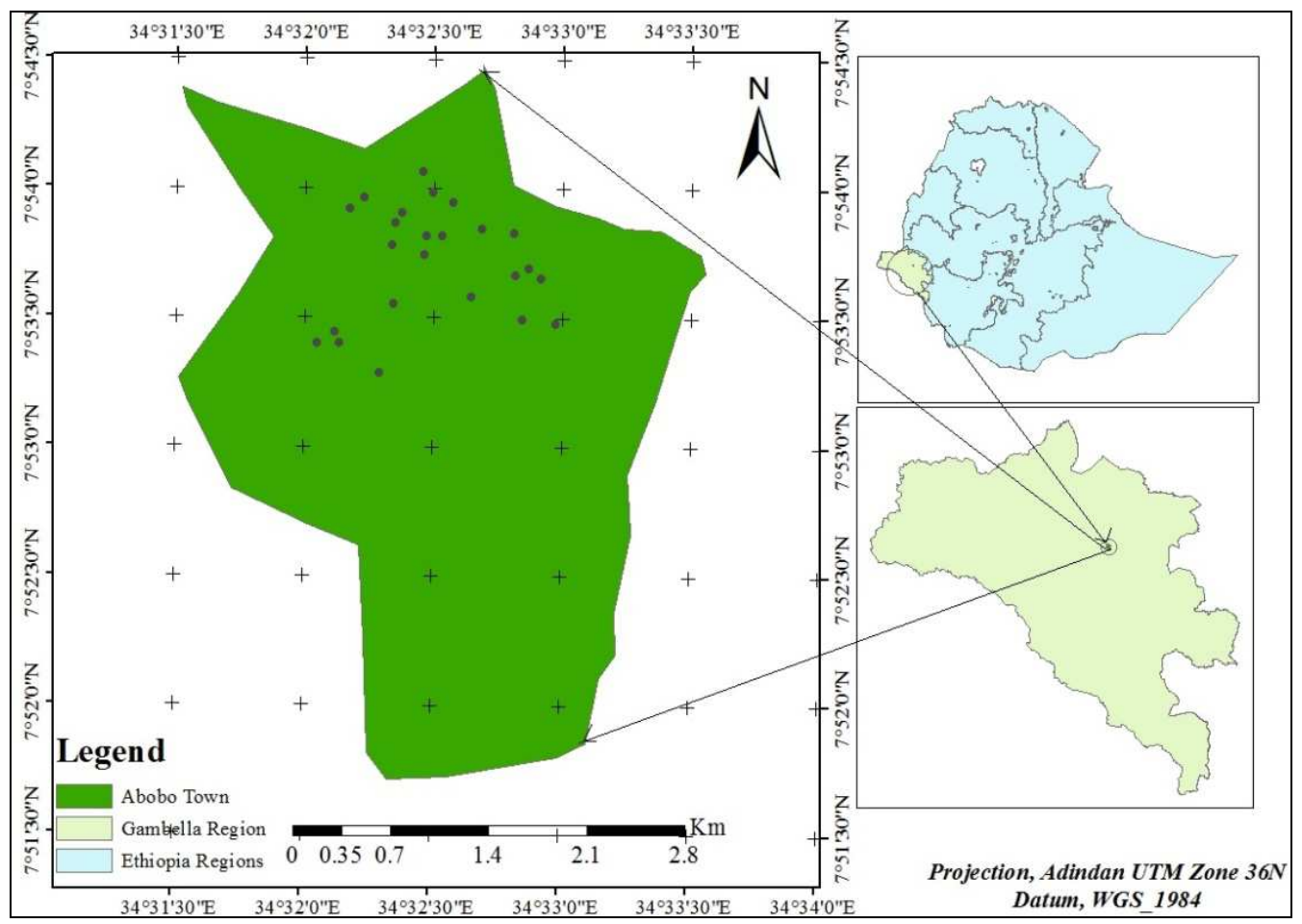

Figure 1. Location map of the study area and the sampling points (Abobo area, southwestern Ethiopia).

Table 1. Mean values of the selected physicochemical properties of soils sampled from different lend use/management practices (data collected in 2012).

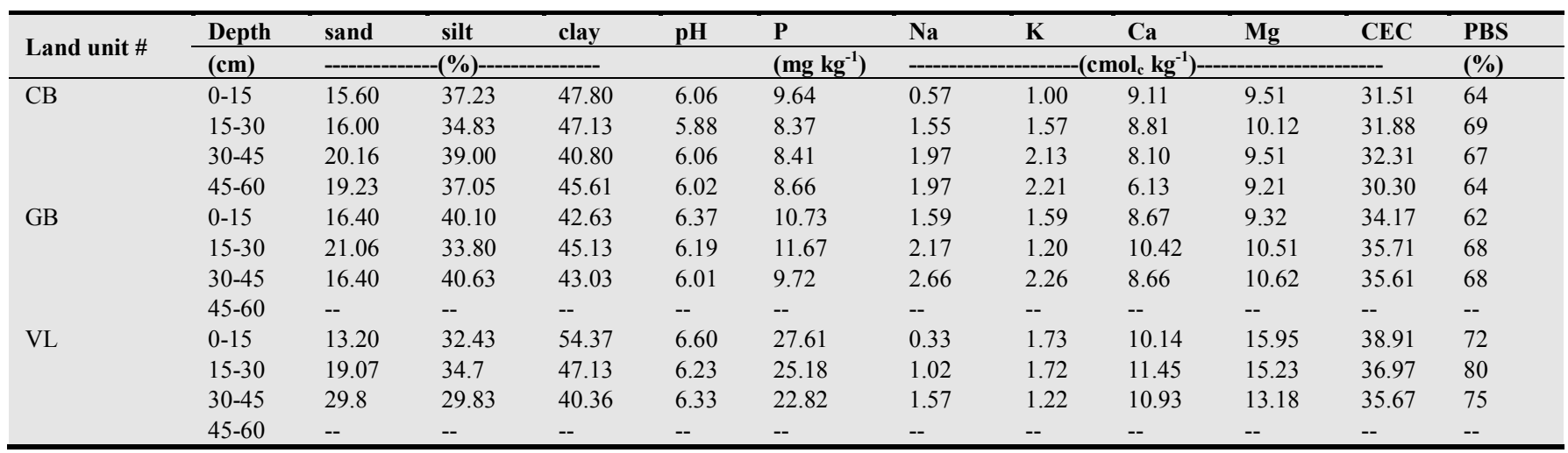

\# CB (long-term cultivated field with annual residue burning) and GB (grassland with annual burning) and VL (virgin forest soil).

-- = Not determined

\subsection{Soil Sample Analysis}

Composite samples collected from the respective depths of each land units were air-dried and crushed to pass a 2-mm sieve, and the selected soil physicochemical parameters were determined in the laboratory, using standard analytical methods. Soil OC was determined by the Walkley-Black wet digestion method [20]. Total $\mathrm{N}$ was determined using the micro-Kjeldahl digestion, distillation and titration procedure
[21]. Soil texture was determined by hydrometer method as described by Van Reeuwijk [22] after dispersion of clays with sodium hexametaphosphate. Available P quantified by Olsen method [23], as the method recommended for all types of Ethiopian soils [24]. The $\mathrm{pH}$ of soil samples were measured in 1:2.5 soil-water ratio. Cation exchange capacity (CEC) was determined after extracting the soil samples by ammonium acetate at $\mathrm{pH} 7.0$ [25]. Exchangeable $\mathrm{Ca}$ and $\mathrm{Mg}$ in the extracts were determined using atomic absorption 
spectrophotometer, whereas $\mathrm{Na}$ and $\mathrm{K}$ were quantified by flame photometer [22], and then percent base saturation (PBS) was computed as:

$$
\mathrm{PBS}=\frac{\mathrm{Mg}^{2+}+\mathrm{Ca}^{2+}+\mathrm{K}^{+}+\mathrm{Na}^{+} \mathrm{y}}{\mathrm{CEC}} \times 100
$$

\subsection{Statistical Analysis}

A one-way analysis of variance (ANOVA) was used to test differences in soil $\mathrm{OC}$ and total $\mathrm{N}$ contents and $\mathrm{C}: \mathrm{N}$ ratio among land units for each soil depth, using the General Linear Model (GLM) procedure of SAS program [26]. All tests of significance were made at $p<0.05$, and the least significant difference (LSD) test to separate means between treatments. Similarly, individual land units were evaluated for soil $\mathrm{OC}$ and total $\mathrm{N}$ contents in the four depths down to $60 \mathrm{~cm}$. Pearson's correlation coefficient analyses were performed to determine the relationships between organic $\mathrm{C}$ and selected soil variables. In addition, the changes due to long-term cultivation and residue burning were determined by comparing the current values of $\mathrm{C}$ and $\mathrm{N}$ under $\mathrm{CB}$ and GB fields with those $\mathrm{C}$ and $\mathrm{N}$ content of undisturbed virgin soils (VL), assuming to have similar properties earlier to the present land uses.

\section{Results and Discussion}

\subsection{Soil Organic Carbon Content}

Analysis of variance (ANOVA) showed an overall significant effect $(p<0.01)$ of land management practices on soil OC contents in all the considered soil depths (Table 2). Across the land units, the mean value of OC ranges between $12.2 \mathrm{~g} \mathrm{~kg}^{-1}$ and $72.7 \mathrm{~g} \mathrm{~kg}^{-1}$ of soil. The largest apparent variation in $\mathrm{OC}$ concentration was found in surface soils (0-
$30 \mathrm{~cm}$ ) of long-term cultivated field (Table 3 ). The reduction of OC from the topsoil $(0-15 \mathrm{~cm})$ under long-term cultivated field with annual burning $(\mathrm{CB})$ and grassland with annual burning (GB) were 83 and $72 \%$, respectively, as compared to the virgin forestland, VL (Fig. 2A). The amount of soil OC decline in $\mathrm{CB}$, in this case, is about $32 \%$ greater than that of reported from the Great Plains soils subjected to intensive cultivation for 60 years [16]. The reduction occurred mostly in the top $30 \mathrm{~cm}$ of soil, although significant reductions were observed in the 30 to $60 \mathrm{~cm}$ depth. This is due to the fact that prolonged cultivation coupled with frequent burning of crop residues practices have been accelerated the rapid turnover rates of organic materials in both fields. Conversely, the virgin soil (VL) produced high mean value of OC (Table 3) which is mainly due to the continuous accumulation of decomposed plant and animal residues in the absence of disturbance of soil environment over a long time period.

Compared to GB field, long-term cultivated field with annual burning (CB) has produced significantly lower quantity of $\mathrm{OC}(p<0.01)$ at the topsoil $(0-15 \mathrm{~cm}$ depth $)$ (Table 3 ), in which the difference in OC corresponds to about $38 \%$ lower than the long-term burned/grass field. However, the concentrations in the all the subsoil depths $(15-60 \mathrm{~cm})$ of both fields were remained statistically at par, that the contents of deeper soil layers $(30-60 \mathrm{~cm})$ in burned/cultivated and burned sites was similar, suggesting that immediate fire/tillage impacts were restricted to the surface soil (0-30 $\mathrm{cm})$. Low quantity of $\mathrm{OC}$ under $\mathrm{CB}$ than $\mathrm{GB}$ field is due to the combined effect of prolonged cultivation and recurrent residue burning practices.

However, despite the absence of such soil disturbance by cultivation practices, periodic burning and removal of grasses in GB field has brought to a considerable decline in OC, compared with the neighboring virgin forest field.

Table 2. Mean square (MS) and results of one-way ANOVA for soil organic carbon (OC) and total nitrogen (TN) contents in different land management at different soil sampling depth.

\begin{tabular}{|c|c|c|c|c|c|c|c|c|c|}
\hline \multirow{2}{*}{$\begin{array}{l}\text { Sampling } \\
\text { depth }\end{array}$} & \multicolumn{3}{|l|}{ OC } & \multicolumn{3}{|l|}{ TN } & \multicolumn{3}{|l|}{$C: N$} \\
\hline & MS & F-value & $p$-value & MS & F-value & $p$-value & MS & F-value & $p$-value \\
\hline $0-15$ & 3265.1 & 6.29 & $<0.0001$ & 6.94 & 150.46 & 0.0002 & 69.42 & 114.54 & 0.0003 \\
\hline $15-30$ & 2631.3 & 424.1 & 0.001 & 4.48 & 28.14 & 0.004 & 93.54 & 33.57 & 0.032 \\
\hline $30-45$ & 324.9 & 41.64 & 0.002 & 0.69 & 18.21 & 0.009 & 32.80 & 578.88 & $<0.0001$ \\
\hline $45-60$ & 29.04 & 16.56 & 0.012 & 0.074 & 26.80 & 0.0048 & 12.30 & 7.48 & 0.045 \\
\hline
\end{tabular}

* Land units: long-term cultivated field with annual residue burning (CB), grassland with annual burning (GB) and virgin forestland (VL).

Table 3. Mean values soil organic carbon $(O C)$, total $N(T N)$ and $C: N$ ratio under different land units are compared within each sampling depth.

\begin{tabular}{|c|c|c|c|c|c|c|c|c|c|c|c|c|}
\hline \multirow{3}{*}{ land units } & \multicolumn{3}{|c|}{$0-15 \mathrm{~cm}$} & \multicolumn{3}{|c|}{$15-30 \mathrm{~cm}$} & \multicolumn{3}{|c|}{$30-45 \mathrm{~cm}$} & \multicolumn{3}{|c|}{$45-60 \mathrm{~cm}$} \\
\hline & OC & $\mathbf{T N}$ & $C: N$ & OC & $\mathbf{T N}$ & $\mathrm{C}: \mathrm{N}$ & OC & $\mathbf{T N}$ & $\mathbf{C} / \mathbf{N}$ & OC & $\mathbf{T N}$ & $C: N$ \\
\hline & \multicolumn{3}{|c|}{$--\left(\mathrm{g} \mathrm{kg}^{-1}\right)--$} & \multicolumn{3}{|c|}{$--\left(\mathrm{g} \mathrm{kg}^{-1}\right)---$} & \multicolumn{3}{|c|}{$---\left(\mathrm{g} \mathrm{kg}^{-1}\right)----$} & \multicolumn{3}{|c|}{$--\left(\mathrm{g} \mathrm{kg}^{-1}\right)---$} \\
\hline $\mathrm{CB}$ & $12.2^{\mathrm{c}}$ & $1.7^{\mathrm{b}}$ & $7.9^{c}$ & $10.9^{b}$ & $1.5^{\mathrm{b}}$ & $6.8^{\mathrm{b}}$ & $10.3^{b}$ & $1.1^{\mathrm{b}}$ & $9.1^{\mathrm{c}}$ & $9.4^{\mathrm{b}}$ & $0.9^{\mathrm{b}}$ & $10.1^{\mathrm{ab}}$ \\
\hline GB & $19.6^{\mathrm{b}}$ & $1.9^{\mathrm{b}}$ & $10.8^{\mathrm{b}}$ & $14.9^{\mathrm{b}}$ & $1.6^{\mathrm{b}}$ & $9.9^{\mathrm{b}}$ & $9.7^{\mathrm{b}}$ & $1.3^{\mathrm{b}}$ & $7.9^{\mathrm{b}}$ & $9.3^{\mathrm{b}}$ & $1.1^{\mathrm{a}}$ & $7.9^{\mathrm{b}}$ \\
\hline VL & $72.7^{\mathrm{a}}$ & $4.4^{\mathrm{a}}$ & $16.7^{\mathrm{a}}$ & $63.8^{\mathrm{a}}$ & $3.6^{\mathrm{a}}$ & $17.7^{\mathrm{a}}$ & $28.1^{\mathrm{a}}$ & $2.0^{\mathrm{a}}$ & $13.8^{\mathrm{a}}$ & $14.6^{\mathrm{a}}$ & $1.2^{\mathrm{a}}$ & $11.8^{\mathrm{a}}$ \\
\hline $\operatorname{LSD}(0.05)$ & 6.12 & 0.49 & 1.76 & 5.64 & 0.48 & 3.78 & 6.36 & 0.44 & 0.54 & 3.01 & 0.11 & 2.91 \\
\hline $\mathrm{CV}(\%)$ & 7.74 & 8.22 & 6.68 & 8.36 & 9.66 & 14.6 & 17.5 & 13.1 & 2.35 & 11.9 & 4.74 & 12.8 \\
\hline
\end{tabular}

Comparison is based on one-way ANOVA and LSD test; Means within column followed by the same letter are not significantly different; triplicate samples for each land management type and depth were used. 
$(p<0.001)$ in OC among the depths of VL, and significant difference $(p=0.05) \mathrm{GB}$ and CB fields (Table 4). Similarly, mean comparison test showed a consistent and significant decrease $(p=0.05)$ with increasing depth of VL field. Compared to their respective surface soils, the amount of soil OC at $45-60 \mathrm{~cm}$ depth was declined by $23 \%, 53 \%$ and $79 \%$, respectively, for burned/cultivated field, burned/grassland and virgin soils. Statistically higher values at $15-30 \mathrm{~cm}$ depth of virgin land than its deeper depths (Table 4), suggest that the layer is still the most biologically active part of the soil profile. In contrast, the decrease of OC was gradual with depth of $\mathrm{CB}$ as compared to other fields, this might be due to disturbances by tillage implements, which could mix different soil layers. This observation is consistent with David et al. [2] who reported the decline in OC in paired fields after 50 year of cultivation in central Illinois.
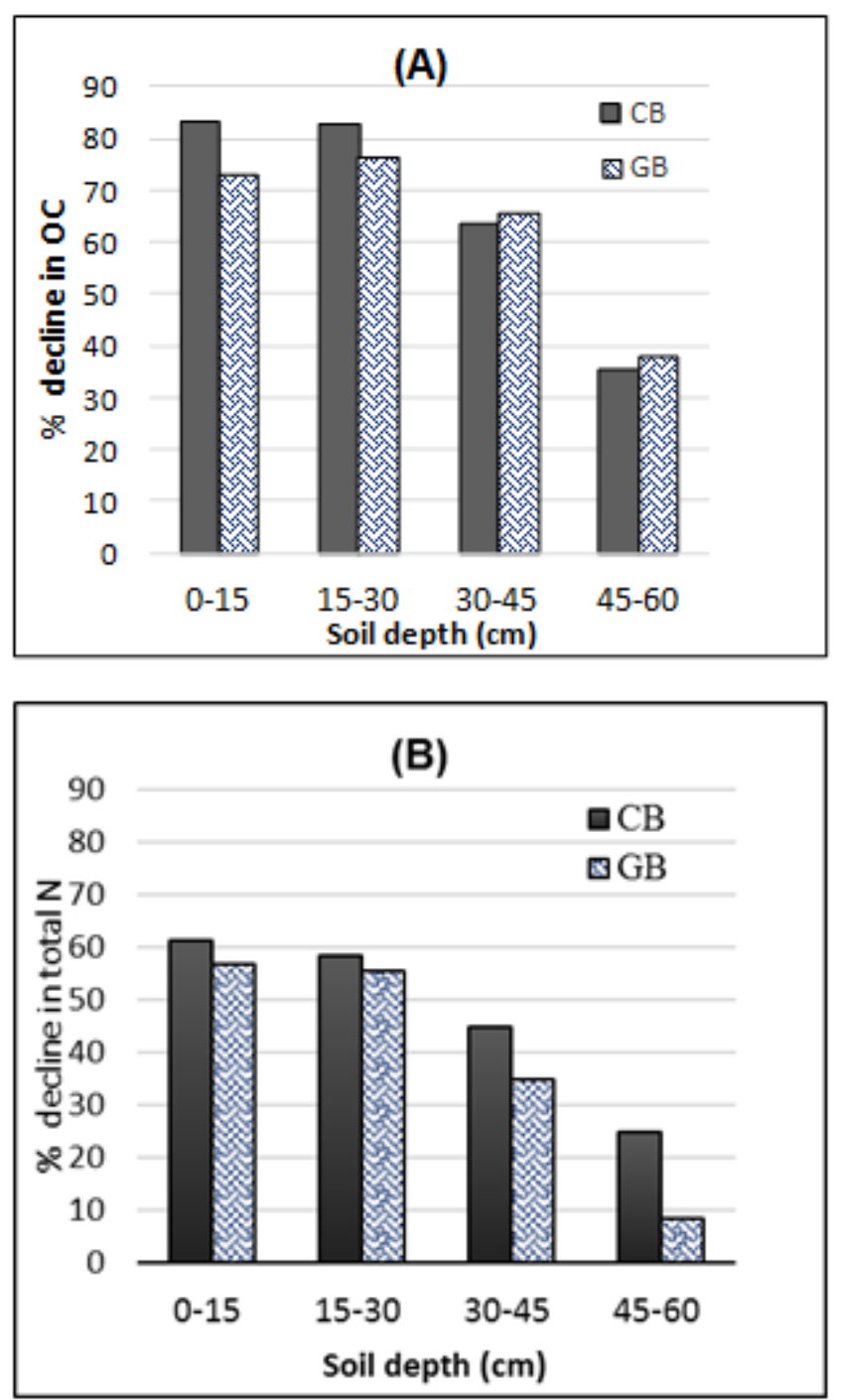

Figure 2. Percentage decline in (A) soil organic carbon contents and (B) total nitrogen contents for each soil depth of $C B$ (long-term cultivated field with annual residue burning) and GB (grassland with annual burning), as compared to virgin forest soils.

Following the ratings for tropical soils [28], the OC concentration of topsoil of both $\mathrm{CB}$ and GB fields qualify for 'low' level; hence such condition could render the soil quality which directly relates to reduced agricultural production. The result supports the suggestions that most cultivated soils of Ethiopia are poor in OC content due to the effect of reduced soil OM $(\sim 58 \% \mathrm{C})$ inputs apparently complete removal of crop residues from cultivated fields [7, 15, 27]. The values obtained under VL are comparable to those reported in forest soils of southern Ethiopia [6, 32] and Alfisols of western highlands Ethiopia [13], however, the magnitude of decline in this case is higher than those reported by the authors mentioned. On the other hand, tremendously higher OC decline (up to $90 \%$ ) from burned soils compared to unburned soils have also been reported $[8,11]$ within a short-term $(<$ 10 year) duration.

\subsection{Total Nitrogen Content}

The result presented in Table 2 indicated that soil total $\mathrm{N}$ content was significantly $(\mathrm{p} \leq 0.01)$ affected by land management in all the measured soil depths. Considering the topsoil $(0-15 \mathrm{~cm})$ of land units, the highest soil total $\mathrm{N}$ content $(4.4 \mathrm{~g} \mathrm{~kg}-1)$ was found in $\mathrm{VL}$, followed by CB $(1.9 \mathrm{~g}$ $\mathrm{kg}-1)$ and GB (1.7 g kg-1). Mean comparison of soil total $\mathrm{N}$ also showed that the forest soil (VL) significantly differ $(\mathrm{p}<$ 0.05 ) in all the soil depths from the soil of other land units, while the values under $\mathrm{GB}$ and $\mathrm{CB}$ remain statistically at par except $30-45 \mathrm{~cm}$ (Table 3). Variations in soil total $\mathrm{N}$ were more pronounced in the top $30 \mathrm{~cm}$ of soil, in which the contents were normally $58-61 \%$ less in $\mathrm{CB}$ compared with VL, whereas $57 \%$ decline in total N content of GB fields (Fig. $2 \mathrm{~B})$. The value observed in surface of $\mathrm{CB}$ was about $27 \%$ greater than that of reported [17] from the nearby site that was subjected to burning and removal of crop residue for several years.

The quantity of total $\mathrm{N}$ was strongly associated with $\mathrm{OC}(\mathrm{r}$ $=+0.59 ; \mathrm{p} \leq 0.01)$ (Table 5), and decreased consistently with increasing soil depth of all land units. Compared to the respective soil depth of the virgin forestland, about 46 and $35 \%(30-45 \mathrm{~cm})$ as well as 25 and $8 \%(45-60 \mathrm{~cm})$ of total $\mathrm{N}$ decline were observed in the subsoil of CB and GB fields, separately. It can be suggested that the low content of total $\mathrm{N}$ in $\mathrm{CB}$ and $\mathrm{GB}$ fields, possibly due to the effects of continuous cultivation and subsequent burning of crop residues, which aggravated the oxidation of organic $\mathrm{C}$. Comparable studies from northwest Ethiopia [33] and boreal interior of Alaska [8] also noticed that frequent burning crop residues had significantly reduced soil total $\mathrm{N}$ contents under cultivated land as compared to the uncultivated counterpart of the same site. Earlier study [14] also reported that surface total $\mathrm{N}$ contents declined by $56 \%$, after cultivation as compared to that of natural forest counterpart.

Soil total $\mathrm{N}$ contents significantly $(p \leq 0.01)$ decreased with the increasing soil depth of VL and GB fields, but the decrease was non-significant $(p>0.05)$ in $\mathrm{CB}$ field and almost similar for soil depths (Table 4). Moreover, in all the land units, the soil depth below $45 \mathrm{~cm}$ was similar decline in total $\mathrm{N}$ concentrations, indicating that the depletion in $\mathrm{OM}$ 
occurred at the upper layers. In general, the amount of total $\mathrm{N}$ at the surface soils of $\mathrm{CB}$ and $\mathrm{GB}$ fields can be rated as 'very low' level [28], whereas the VL field exceeds the 'medium' range. Such decline might have significant consequences on crop production in the area, because OM supplies most of the nitrogen taken up by unfertilized crops [8].

\subsection{Soil Carbon-Nitrogen Ratio}

Soil C:N ratio is often considered as an indication of soil $\mathrm{N}$ mineralization capacity [29]. The mean value of $\mathrm{C}: \mathrm{N}$ ratio of soils varied from $6: 1$ in $\mathrm{CB}$ to $18: 1$ in VL. In all the soil depths, the undisturbed virgin soil (VL) had significantly ( $p \leq$ $0.01)$ higher $\mathrm{C}: \mathrm{N}$ ratio (17:1) than the other soils (Table 3 ). On the contrary, the $\mathrm{C}: \mathrm{N}$ ratio of most of depths in $\mathrm{CB}$ field was found to be narrow, below the 'optimum' range (10 12:1) for arable soils [29]. In fact, natural lands usually have higher $\mathrm{C}: \mathrm{N}$ ratio than prairies and cultivated areas, since cultivation/burning leads to losses of $\mathrm{C}$ and $\mathrm{N}$, but the loss of $\mathrm{C}$ was much higher than the loss of $\mathrm{N}$, the $\mathrm{C}: \mathrm{N}$ ratio narrows. Hence, massive burning of crop residues are reasons for low $\mathrm{C}: \mathrm{N}$ ratios in $\mathrm{CB}$ and $\mathrm{GB}$ fields, and this could accelerate the process of microbial decomposition of OM and $\mathrm{N}$ [10]. This observation is in consistent with earlier studies [14, 28] which reported greater $\mathrm{C}: \mathrm{N}$ ratios in forest soils than agricultural soils.

\subsection{Association of $O C$ with Other Soil Variables}

The computed correlation coefficient indicated a strong and positive association of $\mathrm{OC}$ with some important soil variables: which was highly significant with $\mathrm{CEC}(\mathrm{r}=+0.76$; $p \leq 0.001), \mathrm{P}(\mathrm{r}=+0.72 ; p \leq 0.01)$ and $\mathrm{Mg}(\mathrm{r}=+0.61 ; p \leq$ $0.01), \mathrm{C}: \mathrm{N}(\mathrm{r}=+0.88 ; p \leq 0.001)$, and positive but nonsignificant with $\mathrm{pH}(\mathrm{r}=+0.46 ; p>0.05), \mathrm{Ca}(\mathrm{r}=+0.37 ; p>$ $0.05)$, PBS $(\mathrm{r}=+0.22 ; p>0.05)$ (Table 5). This implies that deprivation of $\mathrm{OC}$ by the existing management practices had also left the soils of $\mathrm{CB}$ and GB fields with a discernible decrease in some vital soil variables. On the other hand, increased soil variables in VL with the soil depth (Table 1) indicates vegetation restoration has implication for improvement of soil nutrients. Equally, as CEC depends largely on clay and OM contents of the soil [29], continuous burning of organic residues had depleted soil OM that attributed to reduction in $\mathrm{CEC}$ of soils in $\mathrm{CB}$ and $\mathrm{GB}$ compared to the undisturbed VL counterpart. The findings are in harmony with the earlier studies $[12,18]$, who reported higher reduction of CEC, PBS and $\mathrm{P}$ contents of soils under comparable management.

Table 4. Mean values for soil OC, total $N$ and $C: N$ ratio of each land units with the soil depth.

\begin{tabular}{|c|c|c|c|c|c|c|c|c|c|}
\hline \multirow{3}{*}{$\begin{array}{l}\text { Sampling } \\
\text { depth }(\mathrm{cm})\end{array}$} & \multicolumn{3}{|l|}{ CB } & \multicolumn{3}{|l|}{ GB } & \multicolumn{3}{|l|}{ VL } \\
\hline & OC & TN & $\mathrm{C}: \mathrm{N}$ & OC & TN & $C: N$ & OC & TN & $\mathbf{C} / \mathbf{N}$ \\
\hline & \multicolumn{3}{|c|}{----( $\left(\mathrm{g} \mathrm{kg}^{-1}\right)----$} & \multicolumn{3}{|c|}{---- $\left(\mathrm{g} \mathrm{kg}^{-1}\right)---$} & \multicolumn{3}{|c|}{----( $\left(\mathrm{g} \mathrm{kg}^{-1}\right)---$} \\
\hline $0-15$ & $12.2^{\mathrm{a}}$ & 1.7 & $7.2^{\mathrm{b}}$ & $19.6^{\mathrm{a}}$ & $1.9^{\mathrm{a}}$ & $10.8^{\mathrm{a}}$ & $72.7^{\mathrm{a}}$ & $4.4^{\mathrm{a}}$ & $16.7^{\mathrm{a}}$ \\
\hline $15-30$ & $10.9^{\mathrm{ba}}$ & 1.5 & $6.8^{\mathrm{b}}$ & $14.9^{\mathrm{b}}$ & $1.6^{\mathrm{b}}$ & $9.9^{\mathrm{a}}$ & $63.8^{b}$ & $3.6^{\mathrm{b}}$ & $17.7^{\mathrm{a}}$ \\
\hline $30-45$ & $10.3^{\mathrm{b}}$ & 1.1 & $9.1^{\mathrm{a}}$ & $9.7^{\mathrm{c}}$ & $1.3^{\mathrm{c}}$ & $7.9^{\mathrm{b}}$ & $28.1^{\mathrm{c}}$ & $2.0^{\mathrm{c}}$ & $13.8^{\mathrm{b}}$ \\
\hline $45-60$ & $9.4^{\mathrm{b}}$ & 0.9 & $10.2^{\mathrm{a}}$ & $9.1^{\mathrm{c}}$ & $1.1^{\mathrm{c}}$ & $7.9^{\mathrm{b}}$ & $14.6^{\mathrm{d}}$ & $1.2^{\mathrm{d}}$ & $11.8^{\mathrm{b}}$ \\
\hline Mean $(60 \mathrm{~cm})$ & 10.5 & 1.3 & 8.3 & 13.5 & 1.5 & 9.1 & 44.8 & 2.8 & 15.1 \\
\hline Significance & * & NS & $* *$ & $*$ & $* *$ & $* *$ & $* * *$ & $* * *$ & $* *$ \\
\hline $\mathrm{CV}$ & 9.78 & 6.1 & 9.7 & 14.3 & 5.97 & 9.6 & 9.18 & 12.1 & 9.31 \\
\hline
\end{tabular}

Soil OC, TN and C:N values of the sampling depths are compared within land unit; comparison is based on one-way ANOVA (LSD test; $<<0.05$ ); values followed by the same letter are not significantly different.

$*, * *, * * *$ indicates that the ANOVA is significant at $0.05,0.01$ and 0.001 probability levels, respectively; NS $=$ non-significant.

Table 5. Pearson's Correlation Coefficients for the selected soil chemical parameters.

\begin{tabular}{|c|c|c|c|c|c|c|c|c|c|c|}
\hline Parameters & pH & $\mathbf{T N}$ & $\mathrm{C} / \mathrm{N}$ & $\mathbf{P}$ & $\mathrm{Na}$ & $\mathbf{K}$ & $\mathrm{Ca}$ & Mg & CEC & PBS \\
\hline $\mathrm{OC}$ & 0.46 & $0.59 * *$ & $0.88 * * *$ & $0.72 * *$ & $-0.64 * * *$ & -0.14 & 0.37 & $0.62 * *$ & $0.76 * * *$ & 0.22 \\
\hline $\mathrm{TN}$ & $0.51 *$ & 1.00 & -0.18 & -0.18 & $-0.51 * *$ & -0.42 & 0.08 & 0.02 & -0.05 & -0.20 \\
\hline $\mathrm{C} / \mathrm{N}$ & 0.31 & 0.02 & 1.00 & $0.88 * * *$ & $-0.49 * *$ & -0.02 & 0.36 & $0.56^{* *}$ & $0.61 * *$ & 0.25 \\
\hline
\end{tabular}

$*, * *, * * *$ indicates that the correlation is significant at $0.05,0.01$ and 0.001 significant levels, respectively.

\section{Conclusions}

Assessing long-term land management effects on soil OC and total $\mathrm{N}$ dynamics is essential for addressing sustainable land productivity issues. Results of the present study showed that the existing management practices significantly affected soil $\mathrm{OC}$ and total $\mathrm{N}$ contents and distribution in all the studied soil depths. Prolonged cultivation coupled with residue burning practices had severely depleted soil OC and total $\mathrm{N}$ contents of the cultivated field, as compared to the uncultivated grassland site. Similarly, great declines in soil OC and total $\mathrm{N}$ content was found in the grass field that has been undergoing annual burning practice, compared with the adjacent virgin forest field. Variations in soil OC was more pronounced at topsoil, and the contents of deeper soil depths in burned and unburned/cultivated sites was more or less similar, suggesting that immediate fire/tillage impacts were restricted to the surface soil depth. On the other hand, positive and strong association of $\mathrm{OC}$ with some soil variables as well as increased soil variables in forest field with its soil depth indicates vegetation restoration has 
implication for improvement of soil nutrients. Since soil organic matter is a key resource of soil nutrients for plant growth, soil structural stability and carbon stock, it must be well managed if agricultural activities were to be sustainable. Thus, precautions should be taken with residue burning to avoid loss of plant nutrients around the root zone, and improvement in soil management (such as fallowing, biomass transfer) should be implemented to ensure sustainability of the farming system. Because, the adverse impacts of residue burning and intensive cultivation are not only dropping input of biomass OC, but also reduction in nutrient cycling, which in turn brought to decline in soil quality.

\section{Acknowledgements}

Funding was provided by the Rural Capacity Building Project (RCBP) for training and research in Ethiopia. My sincere thanks goes to the anonymous field and laboratory assistants for their unreserved collaboration in collecting samples and analyzing the soil parameters. Also, Mr. Ararsa Boki and two anonymous reviewers, who provided helpful suggestions on the manuscript are highly acknowledged.

\section{References}

[1] Jobbágy, E.G., Jackson R.B. The vertical distribution of soil organic carbon and its relation to climate and vegetation. Ecological Applications, 10: 423-436, 2000.

[2] David, M.B. Gregory F.M., Robert G.D., and Rex A.O., LongTerm Changes in Mollisol Organic Carbon and Nitrogen. $J$. Environ. Qual., 38: 200-211, 2009.

[3] Mikhailova, E.A., Bryant R.B., Vassenev, S.J and Post. C.J., Cultivation effects on soil carbon and nitrogen contents at depth in the Russian Chernozem. Soil Sci. Soc. Am. J., 64: 738-745, 2000.

[4] Girma T., Land Degradation: A Challenge to Ethiopia. Environmental Management, 27(6), pp. 815-824, 2001.

[5] Girmay G., Singh B., Mitiku H., Borresen T. And Lal R., Carbon stocks in Ethiopian soils in relation to land use and soil management. Land Degrad. Develop., 19: 351-367, 2008.

[6] Lemenih M., Karltun E., Olsson M., Assessing soil chemical and physical property responses to deforestation and subsequent cultivation in smallholders farming system in Ethiopia. Agriculture, Ecosystems and Environment, 105: 373386, 2005.

[7] Aklilu A, Stroosnijder L., and Graaff J., Long-term dynamics in land resource use and the driving forces in the Beressa watershed, highlands of Ethiopia. Journal of Environmental Management, 83: 448-459, 2007.

[8] Neff, J.C., Harden, J.W., and Gleixner G., Fire effects on soil organic matter content, composition, and nutrients in boreal interior Alaska. Can. J. For. Res., 35: 2178-2187, 2005.

[9] United Nations Country Team March. Ethiopia United Nations Development Assistance Framework 2012 to 2015, 2011
[10] Zhao H, Daniel Q, Tong Q., Xianguo L., Guoping W., Effect of fires on soil organic carbon pool and mineralization in a Northeastern China wetland. Geoderma, 190: 532-539, 2012.

[11] Stan V., Fîntîneru G., Mihalache M. Multicriteria analysis of the effects of field burning crop residues. Not. Bot. Horti. Agrobo, 42(1): 255-262, 2014.

[12] Graham MH., Haynes RJ., Meyer JH. Soil organic matter content and quality: effects of fertilizer applications, burning and trash retention on a long-term sugarcane experiment in South Africa. Soil biology and biochemistry, 34: 93-102, 2002.

[13] Wakene N., and Heluf G. Influence of land management on morphological, physical and chemical properties of some soils of Bako, Western Ethiopia. Agropedology, 13(2): 1-9, 2003.

[14] Tsehaye G., Mohammed A., Effects of Land-Use/Cover Changes on Soil Properties in a Dryland Watershed of Hirmi and its Adjacent Agro Ecosystem: Northern Ethiopia. International Journal of Geosciences Research: 1(1): 45-57, 2013.

[15] Nega E., and Heluf G., Effect of land use changes and soil depth on soil organic matter, total nitrogen and available phosphorus contents of soils in Senbat watershed, western Ethiopia. ARPN Journal of Agricultural and Biological Science. 8(3): 206-212, 2013.

[16] Reeder, J.D., Schuman, G.E., and Bowman, R.A. Soil C and N changes on conservation reserve program lands in the Central Great Plains. Soil Tillage Res., 47: 339-349, 1998.

[17] Yacob A. Soil Characterization for Sustainable Land Management: Potentials and constraints of Ethiopian lowland soils. LAMBERT Academic Publishing, Germany. pp.65-96, 2012.

[18] Yacob A., Heluf G., and Sheleme B. Pedological characteristics and classification of soils along landscapes at Abobo, southwestern lowlands of Ethiopia. J. Soil Sci. Environ. Manage. 5(6): 72-82, 2014.

[19] IUSS Working Group. World Reference base for Soil Resources 2006. $2^{\text {nd }}$ ed. World Soil Resources Reports No. 103. FAO, Rome, 2006.

[20] Walkley, A. and Black, C.A. An examination of the Degtjareff method for determining soil organic matter and modifying the chromic acid method. Soil Science, 37: 29-38, 1934.

[21] Bremner J.M. and Mulvaney C.S. Nitrogen total, pp 595-624. In: A.L. Page (ed). Methods of Soil Analysis, Part II. Chemical and microbiological properties. 2nd ed. American Society of Agronomy, Wisconsin, 1982.

[22] Van Reeuwijk, L.P. (ed.). Procedure for soil analysis, $6^{\text {th }}$ ed. International Soil Reference and Information Centre, Wageningen, the Netherlands, 2002.

[23] Olsen, S.R., Cole, C.V., Watanabe, F.S. and Dean. L.A. Estimation of available phosphorus in soils by extraction with sodium bicarbonate. USDA circular 939. U.S. Govt. Printing, Washington D.C. pp.1-19, 1954.

[24] Tekalign M., and Haque, I. Phosphorus status of some Ethiopian soils. III. Evaluation of soil test methods. Tropical Agriculture, 68: 51-56, 1991.

[25] Chapman, H.D. Cation exchange capacity. In: Black, C.A., Ensminger, L.E. and Clark, F.E. (eds.). Methods of soil analysis. Am. Soc. Agro., 9: 891-901, 1965. 
[26] SAS Institute Inc. SAS Users Guide. Version 9. SAS Institute Inc., Cary, NC. USA, 2002.

[27] Gebeyaw T. Soil fertility status as influenced by different land uses in Maybar, north Ethiopia. MSc Thesis. Haramaya University, Ethiopia. 56p., 2007.

[28] Landon, J.R. (ed.). Booker tropical soil manual: A handbook for soil survey and agricultural land evaluation in the tropics and subtropics. Longman, 1991.

[29] Havlin, J.L., Tisdale, S.L., Nelson, W.L., and Beaton, J.D. Soil Fertility and Fertilizers, $6^{\text {th }}$ ed. Macmillan Publishing. USA, pp.85-196, 1999.

[30] MoA (Ministry of Agriculture). Agro-ecological zones of
Ethiopia. Natural Resource Management and Regulatory Department, Ministry of Agriculture, Addis Ababa, Ethiopia. 1998.

[31] NMSA (National Metrological Service Agency). Report on temperature and rainfall distribution for Abobo District. Abobo Metrological Office, GNRS, Ethiopia, 2012.

[32] Yifru A. and Taye B. Effects of landuse on soil organic carbon and nitrogen in soils of bale, Southeastern Ethiopia. Tropical and Subtropical Agroecosystems, 14: 229 - 235, 2011.

[33] Habtamu K, Husien O, Haimanote B, Tegenu E, Charles F, Amy S, Tammo S. The effect of land use on plant nutrient availability and carbon sequestration. pp 208-219. Proc. $10^{\text {th }}$ conf., March 25-27, Addis Ababa, 2009. 